\title{
Impact assessment of an agricultural technology using economic surplus model : A case of redgram variety (BRG- 1) in Karnataka
}

\author{
C.S. Sathish Gowda*, K.B.Umesh ${ }^{1}$ and Amit Kar \\ Division of Agricultural Economics, IARI, New Delhi (India) \\ (Email : cssg86@gmail.com)
}

\begin{abstract}
Impact assessments significantly differ from monitoring and evaluation. It is essential to demonstrate the success of research outcomes and to understand how research efforts are impact the local communities and thereby accountability to the stakeholders. Economic surplus model is one of the most commonly used methods to assess the economic impact of a technology because of its simplicity and less data requirement. It measures the total economic benefits generated out of a new technology. It is possible to estimate the return to investment by calculating a variation of consumer and producer surplus through a technological change induced by research. The study on economic impact assessment of a technology using economic surplus model for the high yielding variety of Redgram (BRG-1) was carried out in Karnataka in the year 2016. Impact assessment of a technology involves measurement of potential economic benefits generated by the use of new technology. Study uses the agronomic data on yield, production levels, cost of adoption and adoption rate of high yielding variety and farm harvest prices to assess the impact. Net social gain realized out of new variety was Rs. 141 crores. Change in consumer surplus was Rs.106 crores and change in producer surplus was Rs. 35 crores. The internal rate of return was 66 per cent with net present value of Rs. 67 crores from the stream of net social gains at 2011-12 prices. The study on economic impact assessment of a technology using economic surplus model for the high yielding variety of redgram (BRG-1) was carried out in Karnataka in the year 2016. Impact assessment of a technology involves measurement of potential economic benefits generated by the use of new technology. Study uses the agronomic data on yield, production levels, cost of adoption and adoption rate of high yielding variety and farm harvest prices to assess the impact. Net social gain realized out of new variety was Rs. 141 crores. Change in consumer surplus was Rs. 106 crores and change in producer surplus was Rs. 35 crores. The internal rate of return was 66 per cent with net present value of Rs. 67 crores from the stream of net social gains at 2011-12 prices.
\end{abstract}

Key Words : Economic impact assessment, Economic surplus, High yielding variety

View Point Article : Gowda, C.S. Sathish, Umesh, K.B. and Kar, Amit (2018). Impact assessment of an agricultural technology using economic surplus model : A case of redgram variety (BRG-1) in Karnataka. Internat. J. agric. Sci., 14 (2) : 371-375, DOI:10.15740/HAS/ IJAS/14.2/371-375. Copyright@ 2018: Hind Agri-Horticultural Society.

Article History : Received : 19.03.2018; Revised : 01.05.2018; Accepted : 16.05.2018

\footnotetext{
* Author for correspondence:

${ }^{1}$ Department of Agricultural Economics, University of Agricultural Sciences, GKVK, Bangalore(Karnataka) India
} 